\title{
Testing the response of macroinvertebrate functional structure and biodiversity to flooding and confinement
}

\author{
Belinda GALLARDO*, Stéphanie GASCÓN ${ }^{11}$, Mercedes GARCÍA and Francisco A. COMÍN \\ Pyrenean Institute of Ecology (CSIC), Avda. Montañana 1005, 50192 Zaragoza, Spain \\ ${ }^{1)}$ Institute of Aquatic Ecology, University of Girona, Spain \\ *e-mail corresponding author: belinda@ipe.csic.es
}

\begin{abstract}
The aim of the present study was to investigate the relative importance of flooding-and confinement-related environmental features in explaining macroinvertebrate trait structure and diversity in a pool of wetlands located in a Mediterranean river floodplain. To test hypothesized trait-environment relationships, we employed a recently implemented statistical procedure, the fourth-corner method. We found that flooding-related variables, mainly $\mathrm{pH}$ and turbidity, were related to traits that confer an ability of the organism to resist flooding (e.g., small body-shape, protection of eggs) or recuperate faster after flooding (e.g., short life-span, asexual reproduction). In contrast, confinement-related variables, mainly temperature and organic matter, enhanced traits that allow organisms to interact and compete with other organisms (e.g., large size, sexual reproduction) and to efficiently use habitat and resources (e.g., diverse locomotion and feeding strategies). These results are in agreement with predictions made under the River Habitat Templet for lotic ecosystems, and demonstrate the ability of the fourth-corner method to test hypothesis that posit traitenvironment relationships. Trait diversity was slightly higher in flooded than in confined sites, whereas trait richness was not significantly different. This suggests that although trait structure may change in response to the main environmental factors, as evidenced by the fourth-corner method, the number of life-history strategies needed to persist in the face of such constraints remains more or less constant; only their relative dominance differs.
\end{abstract}

Key words: fourth-corner method, biological traits, River Habitat Templet, Mediterranean River

\section{INTRODUCTION}

In recent years, a functional approach to ecosystem analysis based on multiple biological traits of species has provided new insights into the study of aquatic assemblages and their adaptation to environmental constraints (Statzner 2001; Bonada et al. 2006). This functional approach is ecologically meaningful because it takes into account several invertebrate characteristics that can be directly related to ecosystem structure and functionality (Statzner 2001; Statzner et al. 2001). For instance, body shape and attachment to substrate have been related to the ability of invertebrates to resist flooding (Townsend \& Hildrew 1994); aerial respiration has been related to frequent episodes of oxygen depletion (Dolédec et al. 2006); locomotion and substrate relationship have been related to habitat characteristics (Heino 2005); and reproductive strategies have long been related to ecosystem stability (Townsend \& Hildrew 1994). The functional approach is also broadly applicable, providing a useful tool for predicting changes in aquatic structure driven by environmental factors, such as flooding (Townsend et al. 1997), land use (Dolédec et al. 2006), water pollution (Charvet et al. 2000; Gayraud et al. 2003; Dolédec \& Statzner 2007), invasive species (Statzner et al. 2008) and climate change (Bonada et al. 2007).

However, certain problems arise in studying relationships among trait affinity, taxa abundance and envi- ronmental constraints; in particular, how to relate these three aspects simultaneously and how to test the significance of their relationships, a difficulty known as the "fourth-corner problem" (Legendre et al. 1997). A range of trait-based analysis strategies have been used, including clustering species with similar combinations of traits (Usseglio-Polatera et al. 2000a), analyzing the relationship between patterns in species traits and habitat use using multivariate analytical techniques (Dolédec et al. 1996) and weighting the trait affinity of species by their abundance using regression models (Charvet et al. 2000). More recently, Dray and Legendre (2008) provided an improved statistical method to address this issue, namely the fourth-corner statistic. This improved procedure, based on the original method developed by Legendre et al. (1997) offers the opportunity to work with species abundance or presence/absence, and several testing procedures for confirming or rejecting hypotheses positing trait-environment relationships.

Floodplain aquatic environments offer an ideal system for testing such hypotheses because several different environmental situations can be found along the lateral connectivity gradient (Amoros \& Bornette 2002). Moreover, macroinvertebrates are an especially suitable model organism for assessing environmental changes because of their multiple forms, behaviors and habitats used (Rosenberg \& Resh 1993). In this sense, a template for river ecosystems (River Habitat Templet, Townsend $\&$ Hilldrew 1994) enables predictions to be made about 
the traits of species that are more likely to occur under particular conditions. These predictions have been tested for a broad range of aquatic organisms in floodplain habitats, mostly located in the Rhône River (Dolédec \& Statzner 1994; Resh et al. 1994). However, less information is available from other river floodplains, particularly from Mediterranean ecosystems, where floodplain aquatic environments are controlled by changes in habitat structure, salinity and nutrient concentration that are mainly related to floods and droughts, and indirectly to river regulation and agricultural practices (Gasith \& Resh 1999).

Many researchers have stressed the importance of environmental features, such as habitat structure, water chemistry and trophic conditions, in determining the trait-structure of freshwater macroinvertebrate assemblages in both lentic (Wellborn et al. 1996; Heino 2005, 2008) and lotic habitats (Batzer \& Wissinger 1996; Dolédec et al. 2006; Piscart et al. 2006; Mellado et al. 2008). These studies have often documented direct effects of environmental features on the selection of particular life-history strategies, and indirect effects of environmental factors on the abundance and diversity of algae and macrophytes; this latter relationship, in turn, controls the amount of substrates and food resources available for invertebrates (Woodward \& Hildrew 2002). In this context, previous studies have reported adaptations to local environmental conditions, biological interaction and predation along a hydrological connectivity gradient (Dolédec \& Statzner 1994; Resh et al. 1994; Mellado et al. 2008). Therefore, we would expect environmental features that reflect flooding and confinement conditions, as representatives of the two extremes of the hydrological connectivity gradient, to limit the range of life-history strategies of species that inhabit these particular conditions.

It has been suggested that functional biodiversity in frequently flooded sites (i.e., those submitted to extreme environmental constraints) decreases, while that in confined sites (i.e., those reporting highest biotic interaction) increases (Statzner et al. 2004; Mouillot et al. 2006). This suggestion is based on the assumption that unfavorable conditions limit the range of life-history strategies capable of supporting survival, while biotic interaction enhances species competition and trait diversification (Statzner et al. 2004). However, hypotheses that posit differences in functional diversity between flooded and confined sites remain to be tested in floodplain habitats. Because functional diversity, rather than species diversity, is the key driver of important ecosystem processes such as productivity, stability and recovery (Mouillot et al. 2006), a greater understanding of functional diversity should contribute greatly to our knowledge of floodplain functionality and aid in ecosystem management.

To date, the improved fourth-corner methodology has not been used to assess hypotheses concerning trait- environment relationships in floodplain habitats. In the present study, we use this statistical procedure to investigate the relative importance of flooding- and confinement-related environmental features in explaining the macroinvertebrate trait structure in a pool of wetlands located in a Mediterranean river floodplain (Ebro River, NE Spain). Here, we first describe the environmental features and aquatic communities of the Ebro River and its floodplain. Second, we assess the influence of these environmental factors on trait structure by means of the fourth-corner method. Next, we evaluate differences in trait biodiversity between flooded and confined sites. Finally, we discuss the ability of the fourth-corner method to describe the trait structure.

\section{METHODS}

\subsection{Study area}

The Ebro is the largest river in Spain with a watershed area of $85,362 \mathrm{~km}^{2}$, a length of $910 \mathrm{~km}$ and an average annual discharge of $18,138 \mathrm{hm}^{3}$ (CEDEX 1997). In its middle sector, near the city of Zaragoza, the Ebro is a meandering river ( sinuosity $=1.39$, slope $=$ $0.05 \%$ ) with an average $5-\mathrm{km}$ width floodplain. At Zaragoza gauging station, average discharge is $230 \mathrm{~m}^{3}$ $\mathrm{s}^{-1}$ (Spanish Water Authority, URL: http//: www. chebro.es).

The environmental characteristics of the Ebro are similar to those of other Mediterranean rivers, which are distinguished by highly irregular flows caused by the high spatial and temporal variability of the Mediterranean climate (Gasith \& Resh 1999). In the last century, regulation of the river to control flooding and water abstraction has reduced the number and extent of permanent water bodies within the floodplain. Most of the floodplain area is used for agricultural or industrial activities (Torrecilla 2005), and wetlands currently cover only $3.6 \%$ of the total floodplain (Cabezas et al. 2008).

\subsection{Sampling design and procedure}

We selected 17 wetlands in the Ebro River and its floodplain along a 100-km length of the river (Fig. 1). Wetlands were divided in two main groups: those that are permanently connected with the river (flooded sites), and those that are only connected during flood pulses (confined sites). To account for spatial variability, we collected two to three samples at the upstream, midstream and downstream ends within each wetland (see Fig. 1) during two sampling surveys (September 2006 and August 2007). General characteristics of sampled wetlands are shown in table 1 .

\subsubsection{Flooded sites}

Sampling sites within this group are those located in the main river channel (RS), secondary channels (SCs) and backwaters (BWs), all of which are permanently 


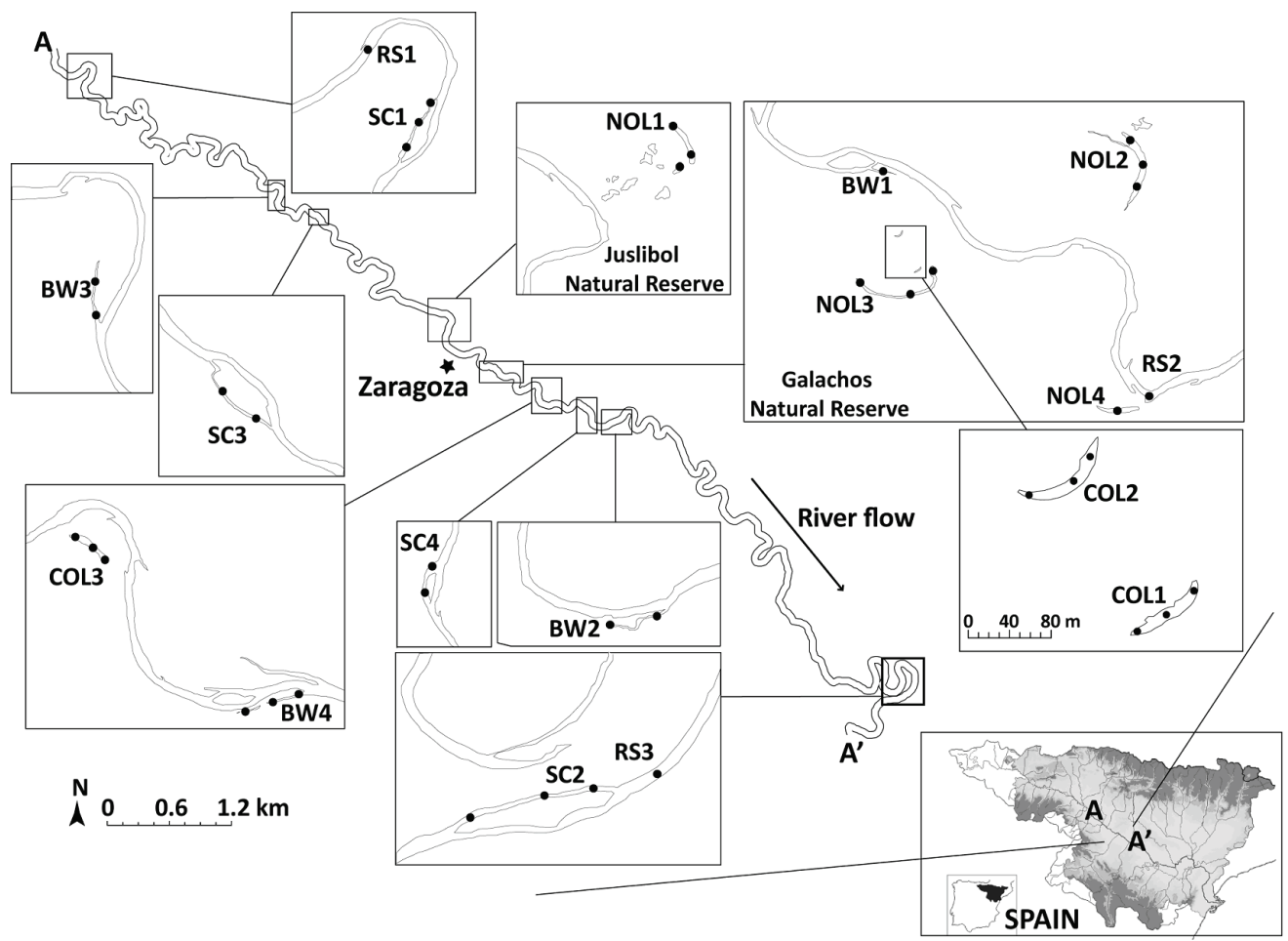

Fig. 1. Study area and site locations. RS $=$ River sites, $\mathrm{SC}=$ secondary channels, $\mathrm{BW}=$ backwaters, $\mathrm{NOL}=$ natural oxbow lakes, $\mathrm{COL}=$ constructed oxbow lakes. Scale bar applies to every enlarged area except COL1 and COL2, which are presented on a different scale. Distance from A to A' is approximately $100 \mathrm{~km}$.

Tab. 1. General characteristics of wetlands monitored in the Ebro River and its floodplain. ${ }^{\text {A }}$ UTM geographical coordinates are referred to the North hemisphere, zone $30 .{ }^{\mathrm{B}}$ Area was measured using summer aerial photographs.

\begin{tabular}{|c|c|c|c|c|c|c|c|}
\hline & Wetland & $\mathrm{X}^{\mathrm{A}}$ & $\mathrm{Y}^{\mathrm{A}}$ & Vegetation & Substrate & $\operatorname{Area}(\text { ha })^{B}$ & Human alteration \\
\hline \multirow{11}{*}{ 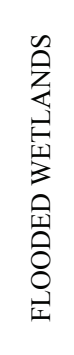 } & RS 1 & 646357 & 4635935 & Emergent/ Submergent & Gravel / Silt & - & Agriculture / Natural \\
\hline & RS 2 & 647186 & 463572 & Emergent/ Submergent & Gravel / Silt & - & Agriculture \\
\hline & RS 3 & 686790 & 4605968 & Emergent/ Submergent & Gravel / Silt & - & Agriculture \\
\hline & $\mathrm{SC} 1$ & 646869 & 4635188 & Emergent/ Submergent & Gravel & 2.22 & Agriculture \\
\hline & SC 2 & 722320 & 4577914 & Emergent/ Submergent & Gravel & 7.5 & Agriculture/ Industrial \\
\hline & $\mathrm{SC} 3$ & 668249 & 4621761 & Submergent & Gravel & 2.09 & Agriculture \\
\hline & $\mathrm{SC} 4$ & 684208 & 4608171 & Herbaceous & Sand & 0.23 & Agriculture / Natural/ Urban \\
\hline & BW 1 & 697289 & 4603333 & Emergent & Silt / Clay & 1.74 & Agriculture \\
\hline & BW 2 & 694396 & 4602628 & Herbaceous & Gravel & 2.1 & Agriculture / Impoundment \\
\hline & BW 3 & 664268 & 4623910 & Herbaceous & Gravel & 2.45 & Industrial/Impoundment \\
\hline & BW 4 & 689689 & 4604661 & - & Gravel & 0.94 & Agriculture / Industrial \\
\hline \multirow{7}{*}{ 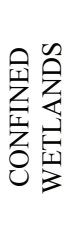 } & NOL 1 & 672608 & 4619264 & Emergent & Silt & 70.31 & Agriculture/ Natural \\
\hline & NOL 2 & 686752 & 4608237 & Emergent & Silt / Clay & 35.45 & Agriculture/ Natural \\
\hline & NOL 3 & 684438 & 4606963 & Emergent & Silt & 10.33 & Agriculture/ Natural \\
\hline & NOL 4 & 686499 & 4605879 & Emergent & Silt & 4.82 & Agriculture/ Urban \\
\hline & COL 1 & 684595 & 4607221 & Emergent/ Submergent & Gravel/ Silt & 0.25 & Agriculture/ Natural \\
\hline & $\mathrm{COL} 2$ & 684412 & 4607559 & - & Gravel & 0.58 & Agriculture/ Natural \\
\hline & $\mathrm{COL} 3$ & 688219 & 4606339 & Emergent & Gravel/ Silt & 4.86 & Agriculture \\
\hline
\end{tabular}

connected to the main river channel at least at one end. RS provided a reference for the river conditions in terms of hydrological connectivity, water quality and invertebrate composition. Although there was less water current in SC sites than in the RS, these sites were permanently connected at both upstream and downstream ends. BW sites were permanently connected to the main channel at their downstream ends, and became reconnected at their upstream ends under intermediate river discharge conditions $\left(200-400 \mathrm{~m}^{3} \mathrm{~s}^{-1}\right)$.

\subsubsection{Confined sites}

Sampling sites within this group included natural and newly created oxbow lakes that do not have a permanent connection with the river channel, and are thus isolated from the river dynamics. While NOLs were flooded at different flow limits (from 400 to $1200 \mathrm{~m}^{3}$ $\mathrm{s}^{-1}$ ), the relatively high elevation of COLs did not allow for a surface connection at river flows $<2500 \mathrm{~m}^{3} \mathrm{~s}^{-1}$. 
Tab. 2. Biological traits and categories for invertebrates considered in the present study.

\begin{tabular}{|c|c|c|c|}
\hline Trait & Categories & Trait & Categories \\
\hline 1. Maximum size & $\begin{array}{l}<2.5 \mathrm{~mm} \\
2.5>\text { size } \leq 5 \mathrm{~mm} \\
5>\text { size } \leq 10 \mathrm{~mm} \\
10>\text { size } \leq 20 \mathrm{~mm} \\
20>\text { size } \leq 40 \mathrm{~mm} \\
40>\text { size } \leq 80 \mathrm{~mm} \\
>80 \mathrm{~mm}\end{array}$ & $\begin{array}{l}\text { 8. Resistance } \\
\text { form }\end{array}$ & $\begin{array}{l}\text { Eggs, statoblasts, } \\
\text { gemmules } \\
\text { Cocoons } \\
\text { Cells against desiccation } \\
\text { Diapause or dormancy } \\
\text { None } \\
\text { Flier }\end{array}$ \\
\hline 2. Respiration & $\begin{array}{l}>80 \mathrm{~mm} \\
\text { Tegument } \\
\text { Gill } \\
\text { Plastron } \\
\text { Spiracle (aerial) }\end{array}$ & 9. Locomotion & $\begin{array}{l}\text { Flier } \\
\text { Surface swimmer } \\
\text { Swimmer } \\
\text { Burrower } \\
\text { Crawler }\end{array}$ \\
\hline $\begin{array}{l}\text { 3. Life cycle } \\
\text { duration }\end{array}$ & $\begin{array}{l}<1 \text { year } \\
>1 \text { year }\end{array}$ & & Interstitial \\
\hline $\begin{array}{l}\text { 4. Potential number } \\
\text { of rep. cycles } y^{-1}\end{array}$ & $\begin{array}{l}<1 \\
1 \\
>1\end{array}$ & 10. Food & $\begin{array}{l}\text { Permanently attached } \\
\text { Deposit feeder } \\
\text { Fine sediments and }\end{array}$ \\
\hline 5. Aquatic stage & $\begin{array}{l}\text { Egg } \\
\text { Larva } \\
\text { Nymph } \\
\text { Adult }\end{array}$ & & $\begin{array}{l}\text { micoorganisms } \\
\text { Detritus }<1 \mathrm{~mm} \\
\text { Plant detritus } \geq 1 \mathrm{~mm} \\
\text { Living microphytes }\end{array}$ \\
\hline 6. Reproduction & $\begin{array}{l}\text { Ovoviviparity } \\
\text { Isolated eggs, } \\
\text { cemented } \\
\text { Clutches, cemented or } \\
\text { fixed }\end{array}$ & & $\begin{array}{l}\text { Living macrophytes } \\
\text { Dead animal }>1 \mathrm{~mm} \\
\text { Living microinv. } \\
\text { Living macroinv. } \\
\text { Vertebrates }\end{array}$ \\
\hline & $\begin{array}{l}\text { Asexual reproduction } \\
\text { Isolated eggs, free } \\
\text { Clutches, free } \\
\text { Eggs or clutches in } \\
\text { vegetation }\end{array}$ & $\begin{array}{l}\text { 11. Feeding } \\
\text { habits }\end{array}$ & $\begin{array}{l}\text { Filter-feeder } \\
\text { Shredder } \\
\text { Scraper } \\
\text { Piercer } \\
\text { Predator }\end{array}$ \\
\hline 7. Dispersal & $\begin{array}{l}\text { Aquatic passive } \\
\text { Aquatic active } \\
\text { Aerial passive } \\
\text { Aerial active }\end{array}$ & & Parasite \\
\hline
\end{tabular}

\subsection{Environmental features}

Dissolved oxygen (DO), temperature and $\mathrm{pH}$ were measured in situ using portable probes $\left(\mathrm{WTW}^{\circledR}\right.$ Multiline P4) that had been previously calibrated. Two-liter water samples were collected from a depth of $20 \mathrm{~cm}$ directly into acid-washed polycarbonate bottles and placed on ice. Samples were filtered on the same day through Whatman ${ }^{\circledR} \mathrm{GF} / \mathrm{F}$ glass-fiber filters (pre-combusted at $450{ }^{\circ} \mathrm{C}$ for $4 \mathrm{~h}$ ) to determine the amount of suspended, dissolved and ash-free solids (APHA 1989). Alkalinity $\left(\mathrm{HCO}_{3}\right)$ was measured using potentiometric automatic titration with $0.04 \mathrm{~N} \mathrm{H}_{2} \mathrm{SO}_{4}$ (APHA 1989). Ionic chromatography was used to determine dissolved inorganic nitrogen concentration (DIN), and a continuous flow analyzer (FLOWSYS-SYSTEA ${ }^{\circledR}$ ) was used to measure the concentration of dissolved organic nitrogen (DON), phosphorus (DOP) and carbon (DOC) (APHA 1989). Phytoplankton photosynthetic pigments (Chl- $a$ ) were analyzed using the Spectrophotometric Method (APHA 1989).

\subsection{Macroinvertebrate traits}

At various microhabitats within each wetland, invertebrates were collected with a sweep net $(45 \times 45$ $\mathrm{cm}$ frame, $500 \mu \mathrm{m}$ sieve) using a 1-min sampling interval covering approximately $0.25 \mathrm{~m}^{2}$ (recording catches per unit effort, CPUE). The microhabitats included emergent vegetation (e.g., Phragmites australis and Typha latifolia), coarse organic matter, littoral areas free of vegetation and stagnant waters. Results from different microhabitats in each sampling point were pooled. Samples were preserved in 5\% formalin and then handsorted and identified to the lowest taxonomic level, usually genus. In this context, it has been shown that taxonomic levels higher than species are suitable for studying the functional structure of communities (Dolédec et al. 1999; Gayraud et al. 2003).

Each trait was composed of 2-8 categories for a total of 60 (e.g., the trait "potential size" was divided into seven categories covering different size ranges). A score was assigned to each genus (ranging from $0=$ no affinity to $3=$ high affinity) according to their affinity for each category, a technique known as "fuzzy coding" (Chevenet et al. 1994). Thus, these affinity scores (extracted from Tachet et al. 2000), were assigned to each taxa for the eleven biological traits considered in this study (Tab. 2).

Trait richness was calculated as the number of trait categories present at a site (Bonada et al. 2007). Trait diversity was calculated as the Rao diversity coefficient 
using the methodology developed by Champely \& Chessel (2002) and implemented in package "ade4" (Chessel et al. 2004) available in R 2.5.1 statistical software (R Development Core Team 2007). Rao's diversity index allows the diversity in a set of species to be measured using trait dissimilarity between the species, and the distribution of species in sites (Champely $\&$ Chessel 2002).

\subsection{Statistical analyses}

First, we used uni- and multivariate analysis of variance (ANOVA and MANOVA) to identify significant differences in environmental characteristics between flooded and confined sites. To reduce the effect of extreme values, variables were previously $\log (\mathrm{X}+1)$ transformed (except $\mathrm{pH})$.

Second, the existing relationship between transformed environmental variables and species abundance was assessed through a canonical correspondence analysis (CCA, ter Braak 1986). To reduce multicollinearity problems, we ran a manual forward selection, and only variables that had a conditional effect significant at the $10 \%$ level ( $p \leq 0.1$, Magnan 1994) were selected. In addition, the inflation factor of selected variables was check to be less than 10 , ensuring a minimum redundancy among the retained variables (ter Braak \& Šmilauer 2002). P-values were calculated using the Monte Carlo Permutation Test (Hope 1968). CCA was performed using CANOCO 4.5 (ter Braak \& Šmilauer 2002).

Third, we used the improved fourth-corner methodology to test the relationships between environmental variables and species traits through the link provided by the abundance of species (Dray \& Legendre 2008). The null hypothesis $\mathrm{H}_{0}$ is that species traits are unrelated to the environmental characteristics of the sites, their relationships being mediated by species abundance. To test this hypothesis, we used a combination of permutation tests, as recommended by Dray and Legendre (2008) which reduces Type I errors and increases the power of the link obtained when the three tables are related. To that end, we first permuted site vectors to test the null hypothesis $\mathrm{H}_{1}$ that the species abundance and the environmental variables are unrelated (permutation model 2, repeated 999 times). After that, we permuted species vectors to test the null hypothesis $\mathrm{H}_{2}$ that the species abundance and the species traits are unrelated (permutation model 4, repeated 999 times). If both permutation tests were significant, then we can reject $\mathrm{H}_{0}$ and thus the environmental conditions, species abundance and traits were considered to be effectively linked. In this sense, if $\alpha_{1}$ is the significant level at which $\mathrm{H}_{1}$ is rejected, and $\alpha_{2}$ is the significant level at which $\mathrm{H}_{2}$ is rejected, then $\alpha_{0}=$ $\alpha_{1} \times \alpha_{2}$ is the significant level at which $\mathrm{H}_{0}$ is rejected, thereby $\alpha_{1}=\alpha_{2}=\sqrt{ } \alpha_{0}$. For instance, at the usual $\alpha_{0}=$ 0.05 significance level, $\alpha_{1}=\alpha_{2}=\sqrt{ } 0.05=0.22$. In our case, however, a Bonferroni correction for the twelve environmental variables was used to finally obtain the significance level $\left(\alpha_{0}=0.05 / 12=0.0042\right)$. As a consequence, the significant levels to reject $\mathrm{H}_{1}$ and $\mathrm{H}_{2}$ (in permutation models 2 and 4 respectively) was considered to be $\alpha_{1}=\alpha_{2}=\sqrt{ } 0.0042=0.064$. For the fourthcorner analysis, we used function "fourthcorner" included in the package "ade4" (Dray \& Dufour 2007) available in R 2.5.1 (R Development Core Team 2007). The description of the original technique developed for presence-absence data can be found in Legendre et al. (1997) and the extension to abundance data is presented in Dray \& Legendre (2008).

Third, we used the non-parametric Wilcoxon Rank sum test to assess differences in trait richness and diversity between flooded and confined sites. We tested the hypothesis that flooded sites have less richness and diversity of traits than confined sites because environmental constraints limit the range of life-history strategies able to cope with flooding disturbance.

\section{RESULTS}

\subsection{General characterization of the study area}

Multivariate analysis of variance (MANOVA) showed that flooded and confined sites significantly differed in their environmental characteristics. Turbidity, inorganic nitrogen and organic phosphorus were significantly higher in flooded than confined sites, while the concentrations of dissolved solids, alkalinity, dissolved oxygen, organic matter, organic carbon and chlorophylla were higher in the latter (Tab. 3).

Tab. 3. Mean (SD) of environmental variables measured in flooded and confined sites in the Ebro River. Temperature in ${ }^{\circ} \mathrm{C}$, all the remaining variables in $\mathrm{mg} \mathrm{L}^{-1} \cdot \mathrm{n}=$ sampling size. Variables in bold showed significant differences between flooded and confined sites (ANOVA, $p<0.05$ ). Results from MANOVA are shown at the bottom.

\begin{tabular}{lcc}
\hline Variable (abbreviation) & $\begin{array}{c}\text { Flooded } \\
(\mathrm{n}=37)\end{array}$ & $\begin{array}{c}\text { Confined } \\
(\mathrm{n}=41)\end{array}$ \\
\hline Turbidity (TSS) & $81.10(70.19)$ & $49.53(54.99)$ \\
Salinity (TDS) & $1601.27(798.64)$ & $1915.89(849.78)$ \\
Alkalinity (HCO) & $204.13(68.19)$ & $214.21(124.72)$ \\
pH & $8.03(0.36)$ & $7.96(0.31)$ \\
Temperature (T) & $20.60(2.66)$ & $20.56(3.35)$ \\
Dissolved Oxygen (DO) & $7.47(2.19)$ & $7.71(2.96)$ \\
Ash-Free Dry Mass (AFDM) & $21.06(16.42)$ & $33.87(22.41)$ \\
Dissolved Inorganic N (DIN) & $4.19(1.69)$ & $1.55(2.90)$ \\
Dissolved Organic N (DON) & $1.24(1.16)$ & $0.51(0.23)$ \\
Dissolved Organic P (DOP) & $27.67(24.14)$ & $17.93(52.82)$ \\
Dissolved Organic C (DOC) & $5.32(3.26)$ & $7.94(4.08)$ \\
Chlorophyll a (Chl- $\boldsymbol{a})$ & $19.13(13.18)$ & $20.94(18.08)$ \\
\hline \multicolumn{3}{c}{ MANOVA Pillai Trace $=0.817 ; F_{12,65}=24.24 ; p<0.001$} \\
\hline
\end{tabular}

The Canonical Correspondence Analysis (CCA) performed with environmental variables and species abundances retained 9 out of 12 environmental variables and explained $32 \%$ of the total variance in species composition (Fig. 2). According to this analysis, flooded wetlands (at the left) were related to the abundance of 


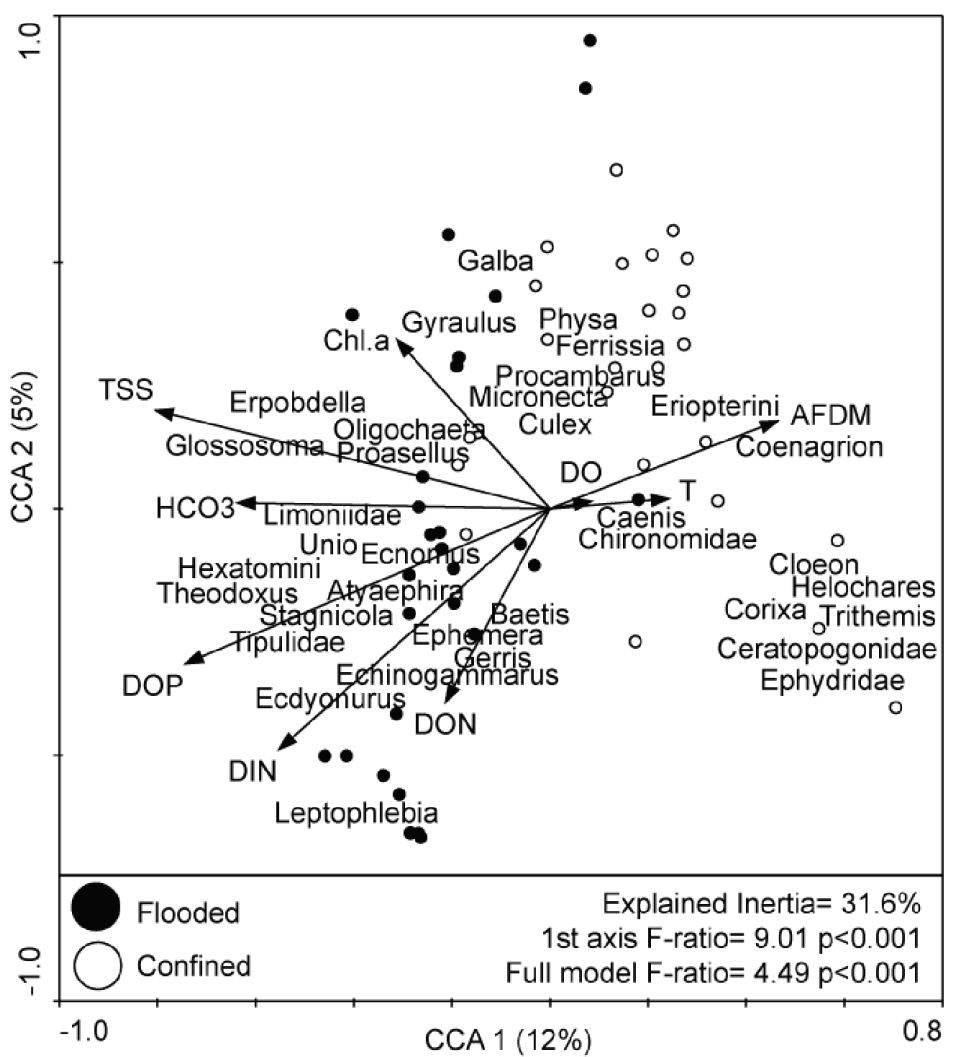

Fig. 2. Results of Canonical Correspondence Analysis performed between species abundance and environmental features in the Ebro river-floodplain.

aquatic worms (e.g., Nais sp.), gastropods (e.g., Stagnicola sp., Theoduxus sp.), crustaceans (e.g., Atyaephira sp., Echinogammarus sp.) and insects (mostly Trichoptera and Ephemeroptera families). By contrast, confined wetlands (at the right) were related to the abundance of gastropods (e.g., Physa sp., Ferrissia sp.), crustaceans (e.g., Procambarus sp.) and insects (mostly Chironomidae, Odonata, Coleoptera and Diptera families).

\subsection{Environmental features affecting the macroinvertebrate trait structure}

The fourth-corner analysis extracted a total of 100 significant relationships between the 12 environmental variables and the 60 biological trait-categories at $\alpha=0.004$.

Environmental variables most significantly related to the invertebrate trait structure (i.e., those accounting for a higher number of significant relationships) included $\mathrm{pH}$, turbidity, water organic matter content and temperature. In contrast, organic phosphorus and oxygen were less significantly related to the macroinvertebrate trait structure (Fig. 3).

On the basis of trait-category responses, environmental variables were divided into two main groups (Tabs 4 and 5). First group included $\mathrm{pH}$, turbidity, inorganic nitrogen, chlorophyll- $a$, alkalinity and organic phosphorus that generally had higher values in flooded sites (except $\mathrm{HCO}_{3}$ and $\mathrm{Chl}-a$ ). Second group included salinity, temperature, oxygenation, water organic matter content, organic nitrogen and phosphorus which generally showed higher values in confined sites (except DON). These two groups of variables showed contrasting relationships with species trait-categories. Hence, trait-categories that showed a general positive relationship with environmental variables in the first group were negatively correlated with environmental variables in the second group, and vice-versa (Tabs 4 and 5).

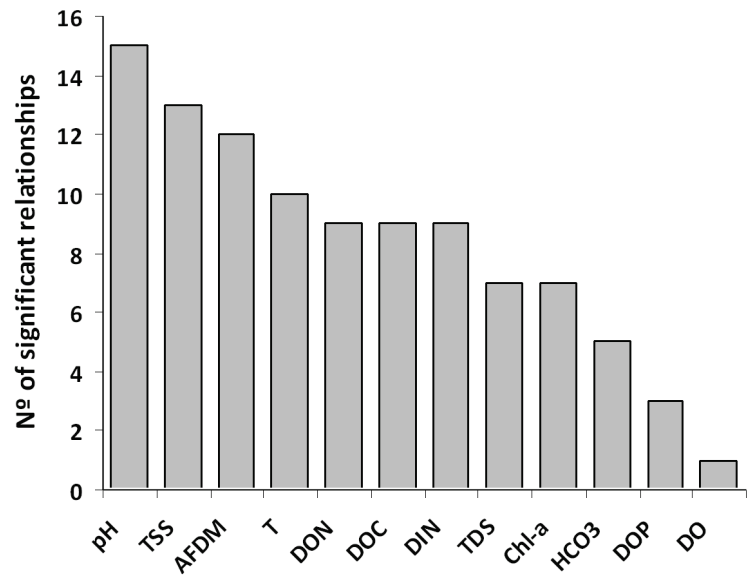

Fig. 3. Number of significant relationships found between each environmental factor and biological trait-categories, obtained by means of the fourth-corner method. 
Tab. 4. Results from fourth-corner analysis performed using species abundance, species functional traits and environmental variables with higher values in flooded sites. The sign (+/-) represents the positive or negative significant Pearson correlation between the environmental variable and the functional trait. For ease of interpretation, only significant relationships $(p<0.004)$ are shown (see methodology for further details on statistical models).

\begin{tabular}{|c|c|c|c|c|c|c|c|}
\hline TRAIT & CATEGORY & $\mathrm{pH}$ & TSS & DIN & Chl- $a$ & $\mathrm{HCO}_{3}$ & DOP \\
\hline \multirow[t]{3}{*}{ 1. Maximum size } & $>2,5 \mathrm{~mm}$ & & + & + & + & & \\
\hline & $>20 \mathrm{~mm}$ & - & & & & - & \\
\hline & $>40 \mathrm{~mm}$ & & - & & & & \\
\hline \multirow[t]{3}{*}{ 2. Respiration } & Tegument & - & & & & & \\
\hline & Gill & & - & & & & \\
\hline & Plastron & & + & + & & & \\
\hline 4. $\mathrm{N}^{\mathrm{o}}$ cycles $\mathrm{y}^{-1}$ & $<1$ & & - & & & & - \\
\hline \multirow[t]{3}{*}{ 5. Aquatic stage } & Egg & + & & & & + & \\
\hline & Nymph & - & & & & & \\
\hline & Imago & & + & + & & & \\
\hline \multirow{2}{*}{ 6. Reproduction } & Cemented eggs & + & & & & & \\
\hline & Free clutches & - & & - & & - & \\
\hline \multirow[t]{3}{*}{ 7. Dispersal } & Aquatic passive & & + & & + & & \\
\hline & Aerial passive & - & & & & & \\
\hline & Aerial active & & - & & - & & \\
\hline 8. Resistance & None & - & & & & & \\
\hline \multirow[t]{4}{*}{ 9. Locomotion } & Swimmer & + & & & & & \\
\hline & Crawler & & & & - & & - \\
\hline & Burrower & - & & & & & \\
\hline & Temp. attached & - & & & & & \\
\hline \multirow[t]{4}{*}{ 10. Food } & Detritus $<1 \mathrm{~mm}$ & - & & & & & \\
\hline & Plant detritus $>1 \mathrm{~mm}$ & & & & & + & \\
\hline & Microinvertebrates & & + & + & & & \\
\hline & Macroinvertebrates & & - & - & & & \\
\hline \multirow{7}{*}{ 11. Feeding habits } & Filterer & - & & & & & \\
\hline & Deposit & - & & & & & \\
\hline & Shredder & & & & + & & \\
\hline & Scraper & & + & & + & & \\
\hline & Piercer & & + & + & & & \\
\hline & Predator & & - & - & - & & - \\
\hline & Parasite & - & & - & & - & \\
\hline
\end{tabular}

Tab. 5. Results from fourth-corner analysis performed using species abundance, species functional traits and environmental variables with higher values in confined sites. The sign (+/-) represents the positive or negative Pearson correlation between the environmental variable and the functional trait. For ease of interpretation, only significant relationships $(p<0.004)$ are shown (see methodology for further details on statistical models).

\begin{tabular}{|c|c|c|c|c|c|c|c|}
\hline TRAIT & CATEGORY & AFDM & $\mathrm{T}$ & DOC & DON & TDS & DO \\
\hline \multirow[t]{2}{*}{ 1. Maximum size } & $>2.5 \mathrm{~mm}$ & - & - & & & - & \\
\hline & $>20 \mathrm{~mm}$ & + & + & + & & & \\
\hline \multirow[t]{2}{*}{ 2. Respiration } & Plastron & - & - & & - & - & \\
\hline & Spiracle & & - & & - & & \\
\hline 4. $\mathrm{N}^{\mathrm{o}}$ cycles $\mathrm{y}^{-1}$ & $=1$ & & & & + & & \\
\hline \multirow[t]{2}{*}{ 5. Aquatic stage } & Egg & - & - & - & & - & \\
\hline & Imago & & & & & - & \\
\hline \multirow[t]{4}{*}{ 6. Reproduction } & Ovoviviparity & & & & + & & \\
\hline & Cemented eggs & - & & - & - & & \\
\hline & Free clutches & + & + & + & & + & \\
\hline & Asexual & & & & & & - \\
\hline 7. Dispersal & Aerial passive & + & + & + & & & \\
\hline 8. Resistance & None & + & & + & + & & \\
\hline \multirow[t]{2}{*}{ 9. Locomotion } & Swimmer & - & & & & & \\
\hline & Perm. attached & & & - & & & \\
\hline \multirow[t]{2}{*}{ 10. Food } & Detritus < $1 \mathrm{~mm}$ & + & + & + & & & \\
\hline & Living macroinv. & & & & - & & \\
\hline \multirow[t]{3}{*}{ 11. Feeding habits } & Filterer & & & & + & & \\
\hline & Piercer & - & - & & - & - & \\
\hline & Parasite & + & + & + & & + & \\
\hline
\end{tabular}



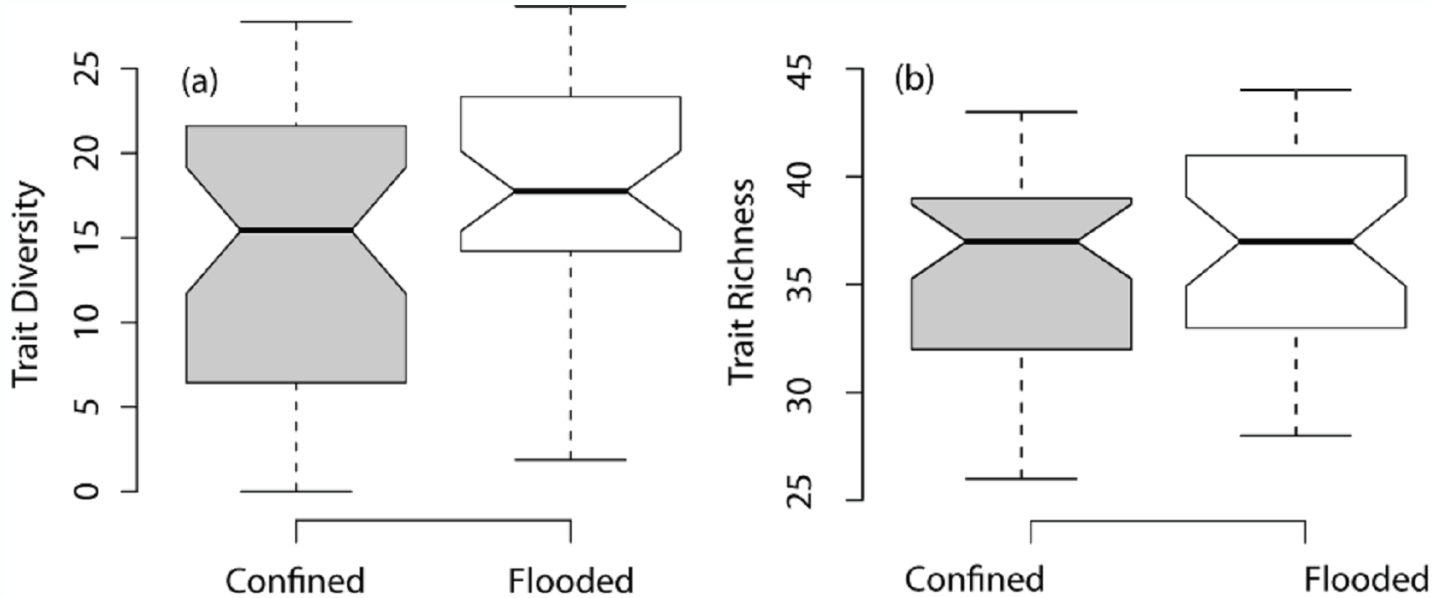

Fig. 4. Trait diversity (a) and richness (b) in flooded and confined sites of the Ebro river-floodplain.

A positive relationship indicated that the abundance of individuals showing a particular trait is expected to increase with increasing levels of the environmental factor, whereas a negative relationship indicates the opposite (i.e., a decrease in the abundance of individuals showing a particular trait at increasing values of the environmental variable). Hence, for ease of comparison, we will only describe these positive relationships between each group of variables and trait-categories in general terms.

Among the flooding-related variables in the first group, $\mathrm{pH}$ and turbidity showed the highest number of significant relationships with trait categories, whereas organic phosphorus and alkalinity showed the lowest (Tab. 4). All of the environmental variables in this category were generally positively related to small-sized organisms $(2.5-5 \mathrm{~mm})$ that exhibited aerial respiration (by plastron), egg or imago stage, used swimming locomotion and were dispersed by aquatic passive means. These variables were also positively related to organisms with reproductive strategies characterized by the production of cemented eggs that were shredder, scraper and piercers, feeding on coarse plant detritus $(>1 \mathrm{~mm})$ and living microinvertebrates.

Among confinement-related variables in the second group, water organic matter content and temperature were most closely related to species traits (Tab. 5). Environmental variables in this second group were found to favor traits such as large size $(>20 \mathrm{~mm})$, aerial passive dispersal and the absence of resistance forms. Environmental variables in the confinement group were related to organisms that produced unprotected (free) clutches or reproduced by ovoviviparity. Finally, the feeding groups associated with the variables in this second group were filterers and parasites, feeding of fine detritus $(<1 \mathrm{~mm})$.

It is worth noting that many trait categories showed no significant relationship with any environmental variable. These included large potential size $(>80 \mathrm{~mm})$, sev- eral reproduction strategies, presence of resistance forms as eggs, cocoons or diapause, and most of locomotion strategies.

\subsection{Response of trait richness and diversity to flooding and confinement}

Trait diversity ranged from 0.82 at NOL1 (a confined oxbow lake) to 28.70 at SC1 (a flooded side channel). Trait richness, in contrast, ranged from 17 traits at NOL3 and COL3 (an oxbow lake and a constructed wetland respectively, both confined) to 44 traits at SC1 and SC3 (both flooded side channels). The non parametric Wilcoxon Rank sum test performed between flooded and confined sites revealed significant differences in trait diversity, which was significantly higher in flooded sites (Wilcox $=582, p=0.08)$. The differences in trait richness, however, were not significant (Wilcox = $609.5, p=0.13$ ) (Fig. 4).

\section{DISCUSSION}

\subsection{General characterization of the study area}

The river and floodplain wetlands of the Ebro River showed distinctive environmental features with respect to flooded and confined conditions. These differences were reflected in highest turbidity and nutrient concentration in flooded sites, and highest salinity, water organic matter content and organic carbon, oxygenation and primary productivity in confined sites. These results are in agreement with a previous Ebro River basin study conducted on a lower geographical scale (Gallardo et al. 2008), as well as with studies performed in other river floodplains (Vandenbrink \& Vandervelde 1994; Heiler et al. 1995; Amoros \& Bornette 2002). In flooded wetlands, the effect of hydrological connectivity on environmental features depends on the balance between sediment scouring, turbidity, turbulence and nutrient inputs; the interplay of these factors often results in increased suspended sediments and inorganic nutrients 
(Heiler et al. 1995). In contrast, dissolved salts and organic nutrients introduced by groundwater seepage and runoff, or generated by autogenic processes, tend to accumulate in confined wetlands (Tockner et al. 1999), eventually leading to salinization and eutrophication. The high concentration of inorganic nitrogen found in flooded wetlands may also be related to extensive agricultural practices, which are reportedly responsible for $66 \%$ of nitrate loads in the Ebro catchment (Torrecilla 2005).

According to multivariate analysis, environmental variables accounted for more than a third of the macroinvertebrate species composition variability. Flooded and confined sites showed distinctive macroinvertebrate composition, in accordance with previous studies performed in the Ebro basin (Gallardo et al. 2008) as well as in other floodplains (Gasith \& Resh 1999; Reckendorfer et al. 2006). In frequently flooded wetlands, invertebrate assemblages has been suggested to be dominated by insect species, particularly from Trichoptera and Ephemeroptera families, as these are considered generalist species capable of resisting survival (Townsend et al. 1997a; Usseglio-Polatera et al. 2000a; Gallardo et al. 2008). The abundance of hirudineans, oligochaetes and chironomids in these sites may be related to the high nutrient concentration of the river. By contrast, crustaceans and insects of Heteroptera, Coleoptera, Odonata and Diptera families became more abundant in confined sites, as these groups are generally supposed to be specialized in habitat and resource exploitation in stable habitats (Townsend et al. 1997a; Usseglio-Polatera et al. 2000a; Gallardo et al. 2008).

\subsection{Main environmental factors determining the trait structure}

It is known that environmental conditions can drive changes in biological traits (Southwood 1988). In this context, we have found evidence that water environmental factors create a template for evaluating the biological traits of organisms that inhabit floodplain wetlands. Based on the response of the trait structure to environmental features obtained using the fourth-corner methodology, we could identify two complementary environmental gradients that structure the functional composition of aquatic invertebrates: flooding and confinement (Fig. 5). These gradients are consistent with the characteristics of the study area and describe trait structure in relation to the respective environmental variability of flooded and confined sites.

The first gradient reflects disturbance of wetlands by flooding, since environmental variables in this gradient (e.g., turbidity, inorganic nutrients) are usually related to river water inputs (Heiler et al. 1995; Amoros \& Bornette 2002). These variables showed a positive relationship with trait categories that confer an ability to (a) resist unfavorable conditions (e.g., small body-shape, protection of eggs), (b) recuperate faster when environmental conditions are less limiting (e.g., short life span, asexual reproduction) (Townsend \& Hildrew 1994), (c) reduce the impact of environmental fluctuations by means of asexual reproduction and the laying of cemented eggs (Townsend \& Hildrew 1994), and (d) effectively colonize new habitats during flooding because of aquatic passive dispersal and swimming locomotion (Mellado et al. 2008). Flooding-related variables have also been suggested to influence feeding habits, enhancing shredders, scrapers and piercers that benefit from organic detritus and attached algae (Heino 2008).

The second gradient, related to confinement, exerted a nearly perfect complementary effect on the selection of traits compared to the first. Certainly, variables in the second gradient (e.g., temperature, salinity, organic nutrients) are usually related to stability or confinement in floodplain habitats (Gallardo et al. 2009). The second gradient was positively associated with traits that allow organisms to interact and compete with other organisms (e.g., large size, sexual reproduction) and to efficiently use habitat and resources (e.g., diverse locomotion and feeding strategies) (Townsend \& Hildrew 1994; Townsend et al. 1997). For instance, large body size, long life span and less than one reproductive cycle per year have commonly been taken as evidence of relatively stable habitats with a low frequency and intensity of flood disturbances (Townsend \& Hildrew 1994; Mellado et al. 2008).

Invertebrate trait responses to those two gradients are good examples of the possible extension of the River Habitat Templet (RHT) proposed by Townsend \& Hilldrew (1994) to lentic habitats. As originally proposed, this theory predicts traits that are more likely to occur under particular habitat conditions in lotic habitats. Accordingly, the first dimension of the RHT focused on the frequency and magnitude of disturbances, which corresponds to the flooding gradient obtained in the present study. The second dimension of the original RHT focused on the role of refugia in buffering the effects of disturbance; in our study, confinement substitutes for this aspect. The extension of the RHT to the entire river-floodplain habitat has been explored for a broad range of aquatic organisms in the Rhône River (Dolédec \& Statzner 1994), where, despite the fact that species traits were significantly related to habitat utilization, the overall results showed little agreement with the RHT predictions (Dolédec \& Statzner 1994; Resh et al. 1994). Such a mismatch was related to the high spatio-temporal heterogeneity of the floodplain ecosystem and the existence of trade-offs (i.e., different strategies used to face the same constraints) and spin-offs (i.e., correlated traits) between traits (Resh et al. 1994). Nevertheless, in the present study, we were able to assess the response of aquatic invertebrates to differences in habitat (flooded vs confined habitats) mediated by differences in environmental characteristics, such as turbidity, salinity, and inorganic and organic nutrient concentration. 


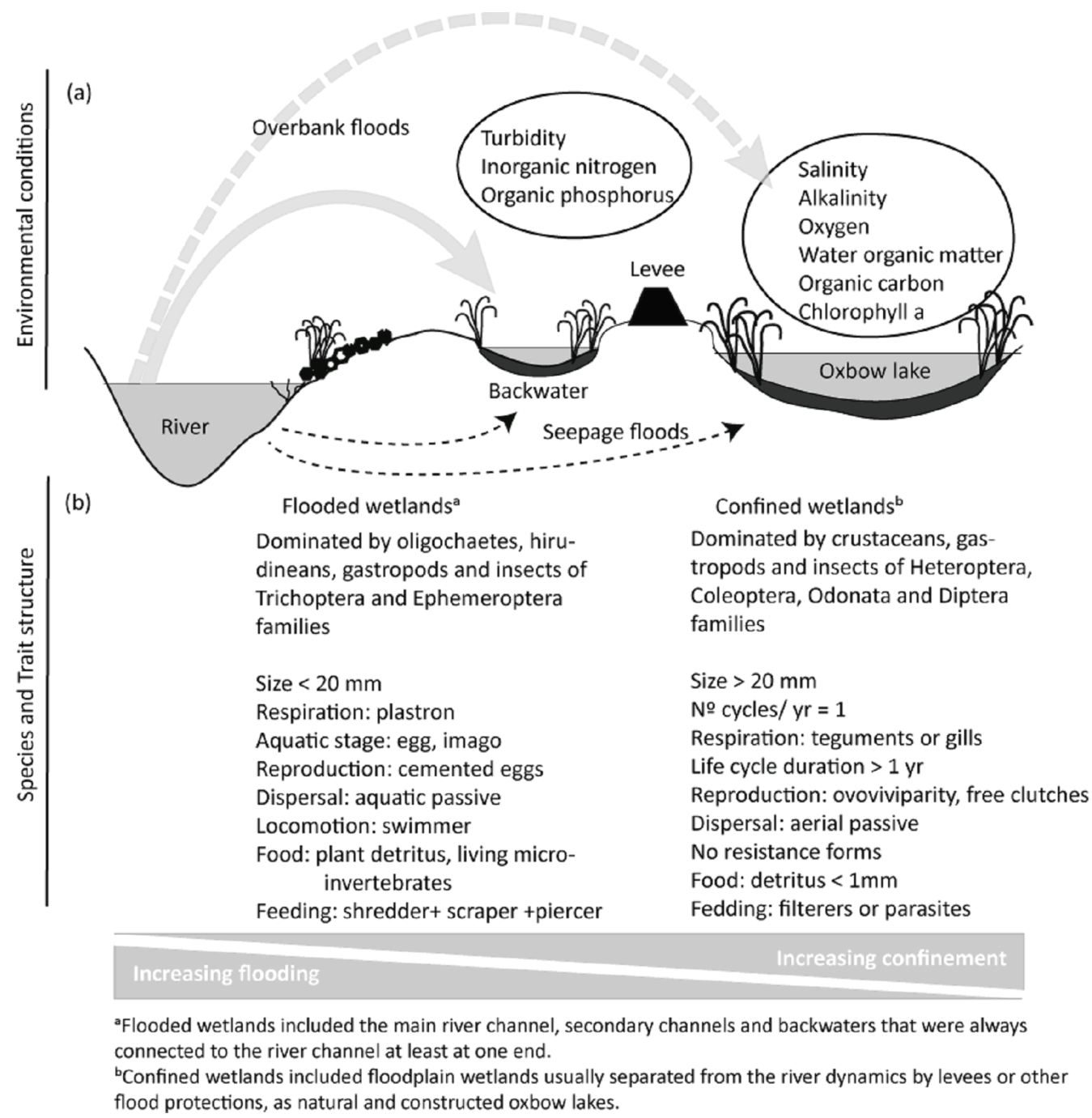

Fig. 5. Template of habitat conditions and response of species and trait structure in the Ebro river-floodplain, based on results from this study. (a) Habitat conditions related to the frequency and duration of flood pulses. (b) Response of the macroinvertebrate species and trait structure to flooding- and confinement-related variables.

\subsection{Response of trait richness and diversity to flooding and confinement}

It has been suggested that functional biodiversity decreases with increasing environmental constraints or stress, as surviving species are more likely to be similar to one another (Statzner et al. 2004; Mouillot et al. 2006). Consistent with these suggestions, we should expect trait richness and diversity to decrease in flooded sites, whereas confined sites should exhibit the opposite response (increased trait richness and diversity). In contrast, we found that trait diversity was slightly higher in flooded sites, whereas trait richness was not significantly different between flooded and confined sites. In this sense, Brinson (1993) reported that less-frequently flooded wetlands are not less functional than frequently flooded ones; the functions are simply different. This suggests that even if trait structure changes in response to the main environmental factors, as evidenced by fourth-corner results, the number of life-history strate- gies needed to cope with such constraints remains more or less constant; only their relative dominance differs. It thus follows that confined sites may have communities with few, highly dominant trait categories, while in flooded sites the dominance of trait categories may be more equally distributed. These changes in dominance could be explained by the stability of the habitat in confined sites, since it is known that stable conditions may lead to the dominance of few organisms (Connell 1978).

An accurate understanding of environmental factors that affect trait biodiversity may be useful for ecosystem management since increasing trait biodiversity may increase overall organism biodiversity and enhance important ecosystem services, such as detritus processing, nutrient cycling, grazing, predation, leaf litter breakdown and energy transfer (Heino 2005). Thus, further research is needed to identify other features beyond flooding and confinement patterns (e.g., vegetation cover, substrate size) that might contribute to trait biodiversity in the Mediterranean floodplains. 


\subsection{The fourth-corner method as a tool for describing biological trait structure}

Dray and Legendre (2008) provided an improved methodology that differs from other statistical options (e.g., Dolédec et al. 1996; Charvet et al. 2000; UsseglioPolatera et al. 2000b) in that it seeks to test the significance of the relationship between every trait and environmental constraint. The fourth-corner method allows relationships among trait affinity, taxa abundance and environmental constraints to be assessed simultaneously, instead of stepwise. Unlike the original method of Legendre et al. (1997), it also allows for the use of abundance data.

Although the modified version of the fourth-corner technique is an improvement over the original, some criticisms remain. For example, as previously noted by Dray \& Legendre (2008), a multiple interaction form of the fourth-corner method that allows covariates to be introduced has yet to be developed; hence, more complicated hypothesis cannot be satisfactorily tested using this approach. Also, the fourth-corner method does not take into account potential correlations among traits (trade-offs and spin-offs), although this limitation is also shared by other statistical alternatives. Dray \& Legendre (2008) also suggested that is possible to obtain false positives using the fourth-corner method in cases where species abundance is related to species traits or environmental characteristics, but not both. This would lead to the incorrect conclusion that a link exists between traits and environmental characteristics that is mediated by species abundance. Nevertheless, the combined testing approach used in this study is one way to solve this problem and offers a powerful tool for testing trait-environment relationships that can be also applied to other ecological studies involving three data-tables (Dray \& Legendre 2008).

Although these various considerations suggest that caveats are in order, the fourth-corner method nonetheless provided evidence to support predictions made under sound ecological frameworks, such as the River Habitat Templet (Townsend \& Hilldrew 1994). In addition, it was easily implemented in the $\mathrm{R}$ programming language. Ultimately, this research may aid in predicting how communities will change in response to given environmental changes, and thereby provide a guide for biodiversity conservation and biomonitoring programs, and efforts to restore and maintain the quality of stream ecosystems (Rosenberg \& Resh 1993; Heino 2005, 2008).

\section{ACKNOWLEDGEMENTS}

This study was supported by the Spanish Ministry of Education (MEC CGL2005-07059-C02-01) and Department of Environment-Aragon Government. Thanks are extended to Stéphane Dray and two anonymous referees for their helpful suggestions that have increased the quality of this paper.

\section{REFERENCES}

Amoros, C. \& G. Bornette. 2002. Connectivity and biocomplexity in waterbodies of riverine floodplains. Freshwat. Biol., 47: 761-776.

APHA. 1989. Standard methods for the examination of water and wastewater. Washington D.C., USA: 1715 pp.

Batzer, D.P. \& S.A. Wissinger. 1996. Ecology of insect communities in nontidal wetlands. Ann. Rev. Entomol., 41: 75-100.

Bonada, N., S. Dolédec \& B. Statzner. 2007. Taxonomic and biological trait differences of stream macroinvertebrate communities between mediterranean and temperate regions: implications for future climatic scenarios. Global Change Biology, 13: 1658-1671.

Bonada, N., N. Prat, V.H. Resh \& B. Statzner. 2006. Developments in aquatic insect biomonitoring: A comparative analysis of recent approaches. Ann. Rev. Entomol., 51: 495-523.

Brinson, M.M. 1993. Changes in the functioning of wetlands along environmental gradients. Wetlands, 13: 65-74.

Cabezas, A., E. González, B. Gallardo, M. García, M. González \& F. A. Comín. 2008. Effects of hydrological connectivity on the substrate and understory structure of riparian wetlands in the Middle Ebro River (NE Spain): Implications for restoration and management. Aquat. Sci., 70: 361-376.

CEDEX. 1997. Estudio sobre el impacto potencial del Cambio Climático en los recursos hídricos y las demandas de agua de riego en determinadas regiones de España. Informe Técnico para el Ministerio de Medio Ambiente, Madrid, Spain. Champely, S. \& D. Chessel. 2002. Measuring biological diversity using Euclidean metrics. Environmental and Ecological Statistics, 9: 167-177.

Charvet, S., B. Statzner, P. Usseglio-Polatera \& B. Dumont. 2000. Traits of benthic macroinvertebrates in semi-natural French streams: an initial application to biomonitoring in Europe. Freshwat. Biol., 43: 277-296.

Chessel, D., A.B. Dufour \& J. Thioulouse. 2004. The ade-4 package. I: One-table methods. $R$ News, 4: 5-10.

Chevenet, F., S. Dolédec \& D. Chessel. 1994. A Fuzzy Coding Approach for the Analysis of Long-Term Ecological Data. Freshwat. Biol., 31: 295-309.

Connell, J.H. 1978. Diversity in tropical rain forests and coral reefs - High diversity of trees and corals is maintained only in a non-equilibrium state. Science, 199: 1302-1310.

Dolédec, S. \& B. Statzner. 1994. Theoretical habitat templets, species traits, and species richness - 548 plant and animal species in the Upper Rhone River and its floodplain. Freshwat. Biol., 31: 523-538.

Dolédec, S. \& B. Statzner. 2007. Invertebrate traits for the biomonitoring of large European rivers: an assessment of specific types of human impact. Freshwat. Biol., 53: 617-634.

Dolédec, S., B. Statzner \& M. Bournard. 1999. Species traits for future biomonitoring across ecoregions: patterns along a human-impacted river. Freshwat. Biol., 42: 737-758.

Dolédec, S., D. Chessel, C.J.F. terBraak \& S. Champely. 1996. Matching species traits to environmental variables: A new three-table ordination method. Environmental and Ecological Statistics, 3: 143-166.

Dolédec, S., N. Phillips, M. Scarsbrook, R.H. Riley \& C.R. Townsend. 2006. Comparison of structural and functional approaches to determining landuse effects on grassland stream invertebrate communities. J. North Am. Benthol. Soc., 25: 44-60.

Dray, S. \& A.B. Dufour. 2007. The ade4 package: implementing the duality diagram for ecologists. Journal of Statistical Software, 22: 1-20.

Dray, S. \& P. Legendre. 2008. Testing the link between species traits and environmental characetristics: the fourthcorner problem revisited. Ecology, 89: 3400-3412. 
Gallardo, B., M. García, A. Cabezas, E. González, M. González, C. Ciancarelli \& F.A. Comín. 2008. Macroinvertebrate patterns along environmental gradients and hydrological connectivity within a regulated river-floodplain. Aquat. Sci., 70: 248-258.

Gallardo, B., S.C. Gascón, A.M. García \& F.A. Comín. 2009. Relationship between macroinvertebrate traits and environmental gradients in a large regulated floodplain Fundamental and Applied Limnology, 173: 281-292.

Gasith, A. \& V.H. Resh. 1999. Streams in Mediterranean climate regions: Abiotic influences and biotic responses to predictable seasonal events. Annual Review of Ecology and Systematics, 30: 51-81.

Gayraud, S., B. Statzner, P. Bady, A. Haybachp, F. Scholl, P. Usseglio-Polatera \& M. Bacchi. 2003. Invertebrate traits for the biomonitoring of large European rivers: an initial assessment of alternative metrics. Freshwat. Biol., 48: 2045-2064.

Heiler, G., T. Hein, F. Schiemer \& G. Bornette. 1995. Hydrological connectivity and flood pulses as the central aspects for the integrity of a river-floodplain system. Regulated Rivers-Research \& Management, 11: 351-361.

Heino, J. 2005. Functional biodiversity of macroinvertebrate assemblages along major ecological gradients of boreal headwater streams. Freshwat. Biol., 50: 1578-1587.

Heino, J. 2008. Patterns of functional biodiversity and function-environment relationships in lake littoral macroinvertebrates. Limnol. Oceanogr., 53: 1446-1455.

Hope, A.C.A. 1968. A simplified monte carlo significance test procedure. Journal of the Royal Statistical Society Series B-Statistical Methodology, 30: 582.

Legendre, P., R. Galzin \& M.L. HarmelinVivien. 1997. Relating behaviour to habitat: Solutions to the fourth-corner problem. Ecology, 78: 547-562.

Magnan, P. 1994. Dietary variation in a fresh-water fish species - relative contributions of biotic interactions, abiotic factors, and spatial structure. Can. J. Fish. Aquat. Sci., 51: 2856-2865.

Mellado, A., M.L.S. Alonso \& M.R.V.-A. Gutierrez. 2008. Biological traits of stream macroinvertebrates from a semi-arid catchment: patterns along complex environmental gradients. Freshwat. Biol., 53: 1-21.

Mouillot, D., S. Spatharis, S. Reizopoulou, T. Laugier, L. Sabetta, A. Basset \& T. D. Chi. 2006. Alternatives to taxonomic-based approaches to assess changes in transitional water communities. Aquatic Conservation-Marine and Freshwater Ecosystems, 16: 469-482.

Piscart, C., P. Usseglio-Polatera, J.C. Moreteau \& J.N. Beisel. 2006. The role of salinity in the selection of biological traits of freshwater invertebrates. Arch. Hydrobiol., 166: 185-198.

R Development Core Team. 2007. R: A language and environment for statistical computing. Foundation for Statistical Computing. Vienna, Austria. (http://www.R-project.org).

Reckendorfer, W., C. Baranyi, A. Funk \& F. Schiemer. 2006. Floodplain restoration by reinforcing hydrological connectivity: expected effects on aquatic mollusc communities. J. Appl. Ecol., 43: 474-484.

Resh, V.H., A.G. Hildrew, B. Statzner \& C.R. Townsend. 1994. Theoretical habitat templets, species traits, and species richness - a synthesis of long-term ecological research on the Upper Rhone River in the context of concurrently developed ecological theory. Freshwat. Biol., 31: 539-554.
Rosenberg, D.M. \& V.H. Resh. 1993. Freshwater biomonitoring and benthic macroinvertebrates. Chapman and Hall, New York: 488 pp.

Southwood, T.R.E. 1988. Tacticts, strategies and templets. Oikos, 52: 3-18.

Spanish Water Authority. URL: http//:www.chebro.es (verified 01 June 2008).

Statzner, B. 2001. Perspectives for biomonitoring at large spatial scales: a unified measure for the functional composition on invertebrate communities in European running waters. Basic and Applied Ecology, 2: 73-85.

Statzner, B., A.G. Hildrew \& V.H. Resh. 2001. Species traits and environmental, constraints: Entomological research and the history of ecological theory. Ann. Rev. Entomol., 46: 291-316.

Statzner, B., S. Dolédec \& B. Hugueny. 2004. Biological trait composition of European stream invertebrate communities: assessing the effects of various trait filter types. Ecography, 27: 470-488.

Statzner, B., N. Bonada \& S. Dolédec. 2008. Biological attributes discriminating invasive from native European stream macroinvertebrates. Biological Invasions, 10: 517-530.

Tachet, H., M. Richoux, M. Bournaud \& P. Usseglio-Polatera. 2000. Invertebrés d'eau douce. CNRS, 588 pp.

Terbraak, C. J. F. 1986. Canonical Correspondence-Analysis a New Eigenvector Technique for Multivariate Direct Gradient Analysis. Ecology, 67: 1167-1179.

Ter Braak, C.J.F. \& P. Śmilauer. 2002. CANOCO Reference manual and CanoDraw for Windows user's guide: sotware for Canonical Community Ordination (version 4.5). Micro Power Ithaca, USA.

Tockner, K., D. Pennetzdorfer, N. Reiner, F. Schiemer \& J.V. Ward. 1999. Hydrological connectivity, and the exchange of organic matter and nutrients in a dynamic river-floodplain system (Danube, Austria). Freshwat. Biol., 41: 521-535.

Torrecilla, N. 2005. Nutrient sources and dynamics in a mediterranean fluvial regime (Ebro River, NE Spain) and their implications for water management. J. Hydrol., 304: 166-182.

Townsend, C.R. \& A.G. Hildrew. 1994. Species traits in relation to a habitat templet for river systems. Freshwat. Biol., 31: $265-275$.

Townsend, C.R., S. Dolédec \& M.R. Scarsbrook. 1997. Species traits in relation to temporal and spatial heterogeneity in streams: A test of habitat templet theory. Freshwat. Biol., 37: 367-387.

Usseglio-Polatera, P., M. Bournaud, P. Richoux \& H. Tachet. 2000a. Biological and ecological traits of benthic freshwater macroinvertebrates: relationships and definition of groups with similar traits. Freshwat. Biol., 44: 563-568.

Usseglio-Polatera, P., M. Bournaud, P. Richoux \& H. Tachet. 2000b. Biomonitoring through biological traits of benthic macroinvertebrates: how to use species trait databases? Hydrobiologia, 422: 153-162.

Vandenbrink, F.W.B. \& G. Vandervelde. 1994. Impact of hydrology and water chemistry on floodplain lake communities along the Lower Rhine and Meuse. Water Science and Technology, 29: 57-60.

Wellborn, G.A., D.K. Skelly \& E. E. Werner. 1996. Mechanisms creating community structure across a freshwater habitat gradient. Annual Review of Ecology and Systematics, 27: 337-363.

Woodward, G. \& A.G. Hildrew. 2002. Food web structure in riverine landscapes. Freshwat. Biol., 47: 777-798.

Received: January 2009

Accepted: May 2009 